\title{
Examining different factors in effectiveness of advertisement
}

\author{
Seyed Gholamreza Jalali Naini, Mohammad Ali Shafia and Negar Nazari*
}

Department of Industrial Engineering, Iran University of Science \& Technology, Tehran, Iran

\begin{tabular}{|c|c|}
\hline A R T I C L E I N F O & ABSTRACT \\
\hline $\begin{array}{l}\text { Article history: } \\
\text { Received October 1, } 2011 \\
\text { Received in Revised form } \\
\text { December, 10, } 2011 \\
\text { Accepted 12 December } 2011 \\
\text { Available online } \\
\text { 14 December } 2011 \\
\text { Keywords: } \\
\text { Advertising } \\
\text { Marketing planning } \\
\text { Informativeness } \\
\text { Shahrvand chain stores }\end{array}$ & $\begin{array}{l}\text { This paper aims to study the effects of different factors on advertising by examining the } \\
\text { simultaneous effects of exposure to the advertisement, type of the media, creativity in } \\
\text { advertisements and being informative. Using data collected from one of the chain supermarkets } \\
\text { of Tehran called "Shahrvand"; the analysis focuses on the effectiveness of four independent } \\
\text { variables and impact of customers' needs on encouraging consumers to purchase. The results } \\
\text { elucidate a relationship among these four variables with encouraging people to purchase. Using } \\
\text { creativity in advertisements, however dominate the effects on this issue. The marketing and } \\
\text { advertisement environment are dynamic and the paper concentrates only on some of the more } \\
\text { effective factors. Producers might be more successful in choosing the best way to promote their } \\
\text { goods and services by following the proposed model. This paper puts four effective factors } \\
\text { together and investigates their impact on advertisement, which was not done by any other } \\
\text { previous papers. Unlike other studies, this paper examines the role of customer needs together } \\
\text { with four other elements on advertisement effectiveness. }\end{array}$ \\
\hline
\end{tabular}

(c) 2012 Growing Science Ltd. All rights reserved.

\section{Introduction}

Encouraging people to purchase certain goods and services and make them attracted to special brands is one of the significant fields of marketing. The advent of varied kinds of goods and services has made the competition among several producers even more intensive. Advertising plays one of the greatest roles in marketing and encouraging people to purchase. Along with the fast progression of the technology, new innovative products are daily launching to the market, therefore the necessity of utilizing the advertising has been more felt after industrialization. According to Bendixon (1993) advertising is an important method that suppliers communicate with their customers in both forms of current and potential. The specific objectives of an advertising campaign may happen in different forms and some of them are as follows,

- Create a preference for the product or brand;

- Create the desired feelings and perceptions of the product or brand;

* Corresponding author. Tel. +982188360401

E-mail addresses: neg.nazari@gmail.com (N. Nazari)

(C) 2011 Growing Science Ltd. All rights reserved. doi: 10.5267/j.msl.2011.12.010 
- Create awareness of a new product or brand;

- Inform customers of the features and benefits of the product or brand;

- Persuade customers to purchase the product or brand.

Advertising is knowledge and the act of informing and influencing people with different purposes such as social, cultural, political and commercial goals and it includes designing, preparation, diffusion, and launching the commercials which all these take an advertising management. With the division of audiences across multiple new media choices generated by the internet in addition to traditional media and the rapid growth of advertising options, firms are pressured to determine how to allocate their advertising monies effectively (Carpenter \& Moore, 2006 ; Chen \& Xie, 2008; Ha et al., 2009; Dholakia \& Zhao , 2009-10; Brettel \& Spilker-Attig, 2010; Fuchs \& Diamantopoulos, 2010; Ha et al., 2011). There are different kinds of advertising such as mass-media advertising, competitive advertising, indirect advertising, direct advertising, consumer advertising, propaganda, advertising image, advertising message, direct-marketing advertising, direct-response advertising, outdoor advertising (Martin et al., 2002; Chiou \& Droge, 2006). The primary objective of promoting goods and services are summarized in the Table 1.

\section{Table 1}

Advertising objectives

Advertising Objectives Explanation

Giving Information Giving information about new products and prices

Encouraging customers Create Preference of the other products

Reminding Reminding and keeping the brand in the public's mind

\subsection{Definition of customer's needs}

Customer's needs are defined in many different ways; it can be defined as desire, requirement, demand and consuming. Generally need is a factor to consume more products in society. As an expression in technical management, need is a physiologic and psychologic shortage, which can make a special achievement attractive.

\subsection{Informativeness}

This attribute has been defined as having the capability of providing the necessary information for target customers (Bendixen, 1993; Ducoffe, 1996; Kim et al., 2010). Consumers of all types of products and services are normally willing to get useful and essential information concerning a specific product. Furthermore, all they need is to have access to information, which is short and to the point. In other words, a good advertisement should be comprehensive and conclusive at the same time. Informativeness can help the consumers make better decisions regarding the right purchase.

\subsection{Type of Media}

With deploying different kinds of media for advertising around the world and spreading out the audiences across the multiple media, the advertising companies are putting much importance to choose the best media for their advertisements. Using the right method and the best way to promote equals the success in attracting more customers. 


\subsection{Using Creativity}

The attribute of creativity is crucially important, because it can attract and allure so many people to watch the commercial or the infomercial. It can also affect consumer purchase intention. Furthermore, the consumer gets entertained beside getting useful information about the product. This attribute is particularly significant due to the fact that it spontaneously stimulate people who are watching the commercials to make a purchase by promoting the enjoyment.

\subsection{Exposure to the advertisements}

The more the consumers face with the exposure to the advertisements, the more they get curious to know about the brand and its advantages. The impact of the message of the advertisement can be enhanced or diminished by frequency of how much they can expose to the advertisement. The proposed model posits that the more one exposes to the advertisements, one brings immediately the advantages of brand to mind by facing it.

The findings of this study should help the producers utilize best factors in the advertisement such as creativity to encourage the customers to make a purchase. On the other hand, it should help customers get informed of new products and services get to know new brands and their advantages in no time.

\section{Theoretical backgrounds and literature review}

In our study, we've looked back to the theoretical background and the several previous studies. In order to conduct this study, great number of papers have been reviewed. Several models have been developed by the time. Some concentrate on consumers' persuasion and some focus on the sequences, which customers take to reach the "act” phase, which refers to purchase.

The modeling regarding advertising effectiveness has developed in clearly two different directions: one is traditional econometric approach and the other is time series analysis. The theory of these two methods has been always seen as competitors up to the time and some econometricians found out they could improve the model by combining these two theories (Leon, 1983; Shum, 2004; Yagci et al., 2009; Wu et al., 2008; Um et al., 2008; Tikkanen et al., 2009).

The elaboration likelihood model (ELM) is a theory, which explains multiple persuasion processes and the variables which clarify these processes (Petty et al., 2004; Rajagopal, 2006; Park \& Lee, 2009). Based on this theory, people are persuaded to purchase when their motivation derives from two different main or peripheral routes. Individuals, who are more interested in the essential nature of a product, incline to search essential information about a specific product. These people are referred to highly-involved consumers who follow the central route of persuasion and are more likely to be affected by the creativity and emotional or entertainment-based attributes of advertisement rather than the essential product information. On the other side, low-involved consumers are people who react by the formats, size and the color of the advertisement, which is referred to as a peripheral route to persuasion (Petty et al., 2004). In time, several other advertising models have been developed. The models AIDA, ACCA, McCarthy 4P, and FCB illustrated the steps one takes to make a decision to purchase.

As to measure advertising effectiveness and clearly describe the development of advertising goals, ACCA model was proposed by Colley (1961) and the main part of this model is the definition of 4 
steps through which the consumers go to make a purchase. The advertising model ACCA consists of 4 factors of Awareness, Comprehension, Conviction and Action. From one point of view, this formula explains a possible sequence of the steps, which bring about purchase. In this meaning, the ACCA is an influence tool and a strategy of advertising. On the other side, it defines subgroups of audience affected by advertising. In this meaning ACCA formula is a measuring tool, a way to define inspection points. By applying ACCA model in our research, the 4 factors of encouraging the customers such as exposure to the advertisement, type of the media, creativity in advertisements and being informative are coordinated with the factors of mentioned model in this order that.

\section{Methodology}

In this Study, the impact of four elements has been explored on the effectiveness of the advertisement. The investigation was designed to examine whether the four mentioned factors affect the consumers' persuasion. On the other hand, we need to know about the important factors, which are more needed to create an influencing advertisement. Therefore, this paper aims to explore the impact of the mentioned factors on consumers' purchase intentions by mediating customers' needs and to find out about consumers expectations from an advertisement and the preference people consider about these four elements. The studied model proposes that the successful advertisement not only have to be informative but also interesting and it has to be broad casted and exposed to the customers several times and by the right media.

In this study, unlike the several previous studies, the goods are not differentiated and all kinds of advertisements for all type of goods are considered.

\subsection{Hypotheses}

Generally speaking, encouraging consumers to make a purchase is associated to several items such as different ways of presenting the items, the position of the goods in the shelves and diverse type of the advertisement. This study focuses on consumers' encouragement by advertisement. Therefore, the followings will be hypothesized in the research model:

H1- Each factors to exposure the advertisement, type of the media, creativity in advertisements and being informative influence on a successful advertisement.

H2-Acknowledging customers' needs has an impact on a successful advertisement.

H3- Launching an advertisement considering the four mentioned factors is coordinated with customer's needs.

\subsection{Data Collection}

Data were collected in different times of the days during one month by people who intended to purchase goods from the store between September and October 2011. Data were compiled by distributing the questionnaires, which included the questions about the variables. The questionnaires were randomly disseminated and collected by hand and were in form of hardcopy for the respondents. Except for demographic attributes, all the items of the questionnaire were measured based on Likert scale, which ranged from strongly agree $=5$, agree $=4$, neutral $=3$, disagree $=2$, strongly disagree $=1$. 


\subsection{Analysis}

By rating the answers, the qualitative data are converted to quantitative ones. One-sample $\mathrm{T}$ test is primarily used in order to accept or reject the hypotheses. Pearson Correlation Matrix is the next test used to illustrate the relationships among the variables. Finally, the four attributes will be classified by Friedman's chi-square test. The results of the test indicate which of the 4 factors is most crucially important to the consumers to influence their purchase intention. The ultimate tests show whether the customers' needs find the accordance to the mentioned attributes.

\subsection{Sample description}

The sample includes 96 customers from one of the branches of chain stores in Tehran based on Cochran formula for sample size determination.

\section{Proposed research model}

The proposed model of this paper contains four independent variables of exposure to the advertisement, type of the media, creativity in advertisements and being informative, one dependent variable of encouraging the consumers to purchase and one mediating variable knowing the customer needs. We expect that this comprehensive model to study the effects of advertising will lead to the best results for a successful advertisement. According to the model ACCA, the comprehensive model for this paper will be:

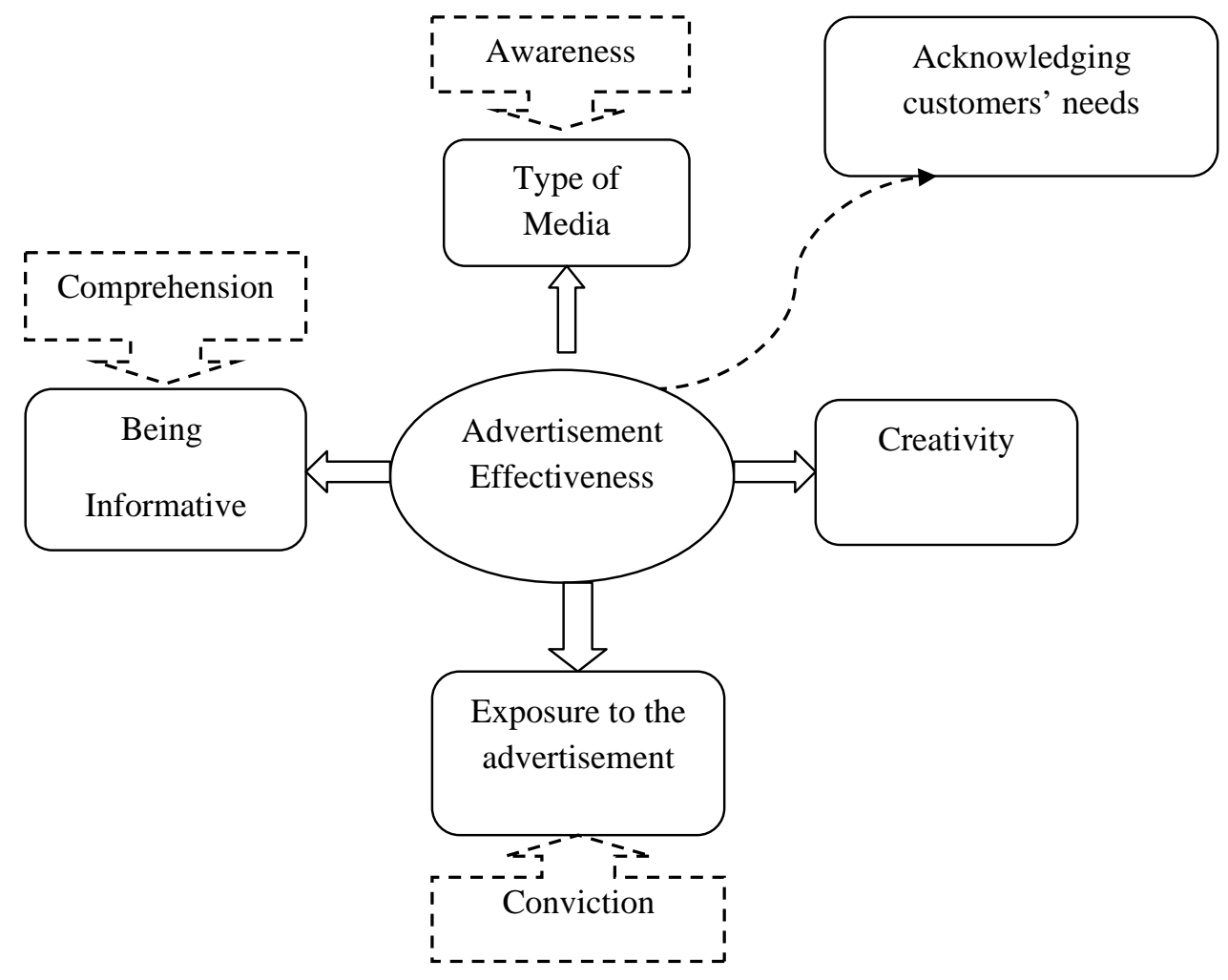

Fig. 1. Proposed research model

\subsection{Data analysis and results}

We collected totally 96 responses and Table 2 illustrates the demographic profile of the respondents. Among the respondents 55 are women and 41 are men, without any missing values in dataset. The 
majority of respondents are in their early and late 30s $(n=31)$. Most of them are employees $(n=49)$ and married $(\mathrm{n}=53)$. Moreover, the majority of the respondents hold Bachelor of Science.

The reliability of the factors was confirmed by conducting Cronbach's alpha test and the items' reliability exceed the acceptable value of 0.7 . The reliability of the factors is provided in Table 3 .

Table 2

Demographic profile

\begin{tabular}{llll}
\hline Items & Category & Frequency & Ratio (\%) \\
\hline \multirow{3}{*}{ Gender } & Male & 41 & 42.7 \\
\hline \multirow{4}{*}{ Age } & Female & 55 & 57.3 \\
& Under 20 & 6 & 6.3 \\
& $20-30$ & 29 & 30.2 \\
\hline \multirow{3}{*}{ Marital Status } & $30-40$ & 31 & 32.3 \\
\hline \multirow{4}{*}{ Education } & $40-50$ & 13 & 13.5 \\
& Over 50 & 17 & 17.7 \\
\hline & Married & 53 & 55.2 \\
& Single & 43 & 44.8 \\
\hline & Pre-high school Diploma & 8 & 8.3 \\
& High school Diploma & 10 & 10.4 \\
& Two year degree & 8 & 8.3 \\
\hline
\end{tabular}

Table 3

The reliability of the factors

\begin{tabular}{ll}
\hline Factors & Reliability \\
\hline Informativeness & 0.792 \\
Type of Media & 0.889 \\
Creativity & 0.790 \\
Exposure to the advertisement & 0.757 \\
Acknowledging customers' needs & 0.878 \\
\hline
\end{tabular}

As it is shown in Table 4, in order to explore the relationship between the factors the Pearson's Correlation test has been conducted. The results show that three factors of creativity, type of media and exposure to the advertisements are accordant with customers' needs, nevertheless there's no accordance between being informative and customers’ needs.

\section{Table 4}

Results of Pearson's Correlation

\begin{tabular}{|c|c|c|c|c|c|c|}
\hline & & $\begin{array}{c}\text { Creativit } \\
\mathrm{y}\end{array}$ & $\begin{array}{l}\text { Type of } \\
\text { Media }\end{array}$ & $\begin{array}{l}\text { Exposure to the } \\
\text { advertisement }\end{array}$ & Informativeness & $\begin{array}{l}\text { Acknowledging } \\
\text { customers' needs }\end{array}$ \\
\hline \multirow[t]{3}{*}{ Creativity } & Pearson correlation & 1 & .034 & $.303^{* *}$ & .060 & $.376^{* *}$ \\
\hline & & & .741 & .003 & .561 & .000 \\
\hline & Frequency & 96 & 96 & 96 & 96 & 96 \\
\hline \multirow[t]{3}{*}{ Type of Media } & Pearson correlation & .034 & 1 & $.399^{* *}$ & .124 & $.220^{*}$ \\
\hline & & .741 & & .000 & .230 & .031 \\
\hline & Frequency & 96 & 96 & 96 & 96 & 96 \\
\hline \multirow{3}{*}{$\begin{array}{l}\text { Exposure to the } \\
\text { advertisement }\end{array}$} & Pearson correlation & $.303^{* *}$ & $.399^{* *}$ & 1 & .186 & $.303^{* *}$ \\
\hline & & .003 & .000 & & .070 & .003 \\
\hline & Frequency & 96 & 96 & 96 & 96 & 96 \\
\hline \multirow[t]{3}{*}{ Informativeness } & Pearson correlation & .060 & .124 & .186 & 1 & .152 \\
\hline & & .561 & .230 & .070 & & .139 \\
\hline & Frequency & 96 & 96 & 96 & 96 & 96 \\
\hline \multirow{3}{*}{$\begin{array}{l}\text { Acknowledging } \\
\text { customers' } \\
\text { needs }\end{array}$} & Pearson correlation & $.376^{* *}$ & $.220^{*}$ & $.303^{* *}$ & .152 & 1 \\
\hline & & .000 & .031 & .003 & .139 & \\
\hline & Frequency & 96 & 96 & 96 & 96 & 96 \\
\hline
\end{tabular}


As shown in Table 5, the studied factors have been graded in sequence. On this basis, creativity has the greatest importance and exposure to the advertisement holds the least significance.

Table 5

The ranking of the factors

\begin{tabular}{lll}
\hline & Factors & \\
\hline 1 & Creativity & 3.01 \\
2 & Type of Media & 2.67 \\
3 & Informativeness & 2.53 \\
4 & Exposure to the advertisement & 1.79 \\
\hline
\end{tabular}

According to the conducted research, several findings have been obtained and to accept or reject the hypothesis one-sample $\mathrm{T}$ test has been carried out. Since for the factors creativity, type of media and being informative $\mathrm{p}<0.05$, null hypothesis is not supported. Therefore, these three factors have impacts on advertising. However, investigating the factor exposure to the advertisements, $\mathrm{p}>0.05$, null hypothesis is accepted. That indicates that this factor does not have much impact on advertisement. When testing second hypothesis, $\mathrm{p}<0.05$, null hypothesis is not accepted and that shows that acknowledging customers' needs influence on adverting. In order to test the third hypothesis Pearson's Correlation test has been conducted. The detailed results are shown in Table 6 and Table 7.

Table 6

The results of one sample $T$ test

\begin{tabular}{lcccc}
\hline Factors & Frequency & Average & Standard Deviation & Standard Error of the Mean \\
\hline Informativeness & 96 & 3.5052 & .72998 & .07450 \\
Exposure to the advertisement & 96 & 3.0417 & .72909 & .07441 \\
Type of Media & 96 & 3.5486 & .55140 & .05628 \\
Creativity & 96 & 3.7229 & .70509 & .07196 \\
\hline
\end{tabular}

Table 7

The results of one sample $\mathrm{T}$ test

\begin{tabular}{|c|c|c|c|c|c|c|}
\hline \multirow[t]{2}{*}{ Factors } & \multirow[t]{2}{*}{$\mathrm{t}$} & \multirow{2}{*}{$\begin{array}{l}\text { Degrees of } \\
\text { freedom }\end{array}$} & \multirow[t]{2}{*}{$\mathrm{P}$} & \multirow{2}{*}{$\begin{array}{c}\text { Difference } \\
\text { with average }\end{array}$} & \multicolumn{2}{|c|}{ Confidence Interval } \\
\hline & & & & & Lower bound & Upper bound \\
\hline Creativity & 10.046 & 95 & .000 & .72292 & .5801 & .8658 \\
\hline Type of Media & 9.748 & 95 & .000 & .54861 & .4369 & .6603 \\
\hline Exposure to the advertisement & .560 & 95 & .577 & .04167 & -.1061 & .1894 \\
\hline Informativeness & 6.781 & 95 & .000 & .50521 & .3573 & .6531 \\
\hline
\end{tabular}

\section{Conclusions}

The main objective of this study was to evaluate the effect of four factors in the effectiveness of advertising, as well as ranking these four factors in encouraging consumers to make a purchase. With this point of view and based on the findings of this study, three factors of creativity, type of media and being informative have an impact on advertising; nevertheless the consumers don't seem to be influenced by exposing several times to the advertisements. On the other hand considering customers' needs and according to the results, the three factors of creativity, type of media and exposure to the advertisements has fulfilled the customers' requirements. That clarifies what exactly customers need to have when needing a special product, is getting the useful information in comparison with the other factors. Creativity is the most crucial factor among three other factors considering customer's needs or not. That means the more creative is an advertisement the more it affects consumers' purchase intention. According to obtained results of testing the hypothesis and ranking the effectiveness of the four studied factors, it is suggested to take creativity in to consideration more than other factors in the 
advertisements. Utilizing innovative and creative advertisements such as according the advertisement with national occasions and designing the ads by innovative persons are useful.

\section{References}

Bendixen, M.T. (1993). Advertising effects and effectiveness. European journal of marketing, 27(10), 19-32.

Brettel, M., \& Spilker-Attig, A. (2010). Online advertising effectiveness: a cross-cultural comparison. Journal of research in interactive marketing, 4(3), 176-196.

Carpenter, J.M. \& Moore, M. (2006). Consumer demographics, store attributes, and retail Format choice in the US grocery market. International Journal of Retail \& Distribution Management, 34(6), 434-452.

Chen, Y., \& Xie, J. (2008). Online Consumer Review: Word-of-Mouth as a New Element of Marketing Communication Mix. Management Science, 54(3), 477-491.

Chiou, J., \& Droge, C. (2006). Service quality, trust, specific asset investment, and expertise: direct and indirect effects in a satisfaction-loyalty framework. Journal of the Academy of Marketing Science, 34(4), 613-627.

Dholakia, R.R. \& Zhao, M. (2009). Retail website interactivity: how does it influence customer satisfaction and behavioural intentions? International Journal of Retail \& Distribution Management, 37(10), 821-838.

Dholakia, R.R. \& Zhao, M. (2010). Effects of online store attribute on customer satisfaction and repurchase intentions. International Journal of Retail \& Distribution Management, 38(7), 482496.

Fuchs, Ch. \& Diamantopoulos, A. (2010). Evaluating the effectiveness of brand-positioning strategies from a consumer perspective. European Journal of Marketing, 44(11/12), 1763-1786.

Ha, H., John, J., Janda, S \&, Muthaly, S. (2011). The effects of advertising spending on brand loyalty in service. European journal of marketing, 45(3), 673-691.

Kim, J. U.K., Kim, W.J. \& Park, S. Ch. (2010). Consumer perception on web advertisements and motivation factors to purchase in the online shopping. Computers in human behavior, 1208-1222.

Martin, B.A.S., Bhimy, A.C., \& Agee, T. (2002). Infomercials and advertising effectiveness; an impiracal study. Journal of consumer marketing, 19(6), 468-480.

Netemeyer, R.G., Krishnan, B., Pullig, C., Wang, G., Yagci, M., Dean, D., et al. (2004). Developing and validating measures of facets of customer-based brand equity. Journal of Business Resources, 57(2), 209-224.

Park, C \& Lee T.M. (2009). Information direction, website reputation and eWOM effect: A moderating role of product type. Journal of Business Research, 62(1), 61-66.

Rajagopal (2006). Insights from research brand excellence: measuring the impact of advertising and brand personality on buying decisions. Measuring Business Excellence, 10(3), 56-65.

Shum, M. (2004). Does advertising overcome brand loyalty? Evidence from the breakfast-cereals market. Journal of economics and management strategy, 13(2), 241-272.

Tikkanen, H., Hietanen, J., Henttonen, T. \& Rokka, J. (2009). Exploring virtual worlds: success factors in virtual world marketing. Management Decision, 47(8), 1357-1381.

Um, N.H. (2008). Revisit Elaboration Likelihood Model: How Advertising

Appeals Work on Attitudinal and Behavioral Brand Loyalty Centering Around Low vs. HighInvolvement Product. European Journal of Social Sciences, 7(1), 126-139.

Wu, C.S., Cheng, F.F. \& Yen, D.C. (2008).The atmospheric factors of online storefront Environment design: an empirical experiment in Taiwan. Information \& Management, 45(7), 493-498.

Yagci, M.I., Biswas, A \& Dutta, S. (2009). Effects of comparative advertising format on consumer responses: The moderating effects of brand image and attribute relevance. Journal of business research, 62, 768-774. 